\title{
THE EFFECT OF SHORT TIME THERMAL TREATMENT ON SWELLING OF FIELD MAPLE (ACER CAMPESTRE L.) AND FIR (ABIES ALBA MILL.)
}

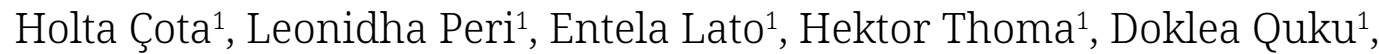 \\ Laura Shumka²
}

\footnotetext{
${ }^{1}$ Department of Wood Industry, Faculty of Forestry Sciences, Agricultural University of Tirana, 1029 KoderKamez, Tirana, Albania

${ }^{2}$ Department of Architecture, Faculty of Applied and Economic Sciences, Albanian University, Rruga e Kavajës 121, Tirana, Albania
}

Link to this article: https://doi.org/10.11118/actaun202068030483

Received: 22. 2. 2020, Accepted: 16. 6. 2020

To cite this article: ÇOTA HOLTA, PERI LEONIDHA, LATO ENTELA, THOMA HEKTOR, QUKU DOKLEA, SHUMKA LAURA. 2020. The Effect of Short Time Thermal Treatment on Swelling of Field Maple (Acer campestre L.) and Fir (Abies alba Mill.). Acta Universitatis Agriculturae et Silviculturae Mendelianae Brunensis, 68(3): 483-490.

\begin{abstract}
From the immemorial time wood is highly abundant and well-performing material. Further one due to practical use the wood heat treatment, as a process for improving its properties has been enhanced in the recent tim. Abies alba Mill and Acer campestre L. are among the most wide spread species in Albanian forest and among the most useful types of wood in Albanian wood industry. The objective of this study is to investigate the influence of short time heat treatment on dimensional stability and the mass loss of these two species. Wood samples are treated in three different temperatures $\left(180^{\circ} \mathrm{C}\right.$, $200^{\circ} \mathrm{C}, 220^{\circ} \mathrm{C}$ ) and two different time durations of 15 and 30 minutes. After the heat treatment, the mass loss is determined for treated samples. Treated and untreated samples are immersed in water and the swelling is determined. According to the results obtained, wood swelling undergoes a considerable reduction in the case of wood treatment at a temperature of $220^{\circ} \mathrm{C}$ for the longest time duration of 30 minutes. The higher percentage of weight loss after the thermal treatment $(9.66 \%$ for the maple and $10.77 \%$ for the fir) was measured in the samples treated in a $220^{\circ} \mathrm{C}$ for 30 minutes. The results of both treated and untreated wood were given for comparative purposes.
\end{abstract}

Keywords: wood treatment, thermal applications, maple, fir, swelling, wood modification, timber processing

\section{INTRODUCTION}

As an alternative method to the wood preservation through use of chemical agents is considered the thermal treatment (Vernois, 2001; Militz, 2002; Chanrion and Schreiber, 2002), considering this one not only as an approach for removes water from wood but also causes significant transformation in the chemical composition of wood (Kocaefe et al., 2008). From the immemorial time wood materials are widely used and dependable material for construction works and used in a very broad range of applications like furniture, building, road works, water works etc. The large variety in timber species guarantees that there is always a species with the required properties for a specific purpose. The economic impact of timber products is therefore considerable. Following Grönquist et al. (2019) wood also has a number of disadvantages in case of furniture because it is a hygroscopic material, while have advantage for self-shaping timber elements, while other studies (Holstov et al., 2015; Rüggeberg et al., 2015) have been done in order to improve the disadvantageous properties of wood. 
The methods brought out based on the results of these studies are commonly named "wood modifications". More modifications of wood can be defined as a process that improves the properties of wood, producing a new material that when disposed at the end of the product life cycle doesn't present an environmental hazard any greater than unmodified wood (Hill, 2006). Further on the heat treatment is a wood modification method as well. The principal effect gained by heat treatment of wood is reduced hygroscopicity (Grönquist et al., 2019) with an main advantages of wood treated in this manner are increased resistance to different types of biodegradation and improved dimensional stability, without the use of (toxic) chemicals (Kocaefe et al., 2008). Further on the heat treatment changes some physical, mechanical and chemical properties of wood, that is, dimensional stability, equilibrium moisture content (EMC), color of wood, bending strength, relevant strength, hardness, amount of wood polymers, biological durability etc. (Mazela et al., 2004; Yildiz et al., 2006; Gündüz et al., 2008). In the recent decades there has been conducted series of surveies in order to improve the disadvantages of wood, started from 1920 when Tiemann showed that the drying at high temperatures decreased the equilibrium moisture. (Kollman, 1936; Stamm and Hansen, 1937; Seborg et al., 1945) used heat treatment to improve the wood disadvantages.

Since the 1950's research has been done on thermal modification of wood, based on heat treatment of (fresh or conditioned) wood at relative high temperatures: $230-260{ }^{\circ} \mathrm{C}$ (Seborg et al., 1953; Kollmann and Schneider, 1963; Stamm and Hansen, 1937; Kollmann and Fengel, 1965; Noack, 1969; Burmester, 1973 and 1975; Giebeler, 1983; Hillis, 1984; Bourgois and Guyonnet, 1988). The approaches on heat treatment indicated that heat treatment of wood improves wood physical properties by reducing hygroscopicity and improving dimensional stability (Viitaniemi, 1997; Santos, 2000). In different European research teams were developed methods that are based on thermal treatment of wood (e.g. Bourgois and Guyonnet, 1988; Viitaniemi and Jämsä, 1996; Boonstra et al., 1998; Sailer et al., 2000; Weiland and Guyonnet, 2003). The key differences between these methods are based on the materials used (e.g. wood species, fresh or dried wood, moisture content, dimensions), process conditions applied (e.g. one or two process stages, wet or dry process, heating medium, oxygen or nitrogen as sheltering gas, heating and cooling down velocity) and the equipment necessary for treatment (e.g. process vessel, kiln). In these contexts different types of commercial heat treatments are developed in Europe. Several wood species are used, with different process conditions, depending on species and the final use of the product. All these processes use sawn wood and treatment temperatures vary from $160^{\circ} \mathrm{C}$ to $260^{\circ} \mathrm{C}$. Researchers use long time heat treatment, which means a time more than 2 hours in order to affect the physical and chemical properties of wood as (4, 8 and $12 \mathrm{~h}$ - Kocaefe et al., 2008; $8 \mathrm{~h}$ - Hakkou et al., 2006; 2-24 h - Esteves et al., 2008; 2-8 h Akyildiz et al., 2009, etc). On the other hand there are also some approaches using short duration heat treatments that have been carried out. (Mburu et al., 2007) applied short time of heat treatment of $30 \mathrm{~min}$ as well as long time duration of 1, 5, 7, 15 hours to evaluate the resistance against termites and several wood fungi. They used Grevillea robusta an African wood species of low durability, treated at temperatures of $240^{\circ} \mathrm{C}, 250^{\circ} \mathrm{C}$ and $260^{\circ} \mathrm{C}$. It was shown that the durability of this wood was increased against termites and basidiomycetes even when the duration of heat treatment was short (30 min). Shi et al. (2007) studied the resistance of thermallymodified and ACQ-C treated aspen (ACQ-C: copperammonia and/or copper-ethanolamine), jack pine, yellow poplar and Scots pine against the brown the brown-rot fungus and Eastern U.S subterranean termite. They treated the wood at $210^{\circ} \mathrm{C}$ for $15 \mathrm{~min}$. The results showed that the thermally- modified wood was less resistant to fungus decay and termite attack than ACQ-C treated wood. Kocaefe et al. (2010) studied the effect of heat treatment conditions on the mechanical properties of North American pine. The wood was treated in different temperatures $\left(120^{\circ} \mathrm{C}, 160{ }^{\circ} \mathrm{C}, 200^{\circ} \mathrm{C}, 210^{\circ} \mathrm{C}, 220^{\circ} \mathrm{C}, 230^{\circ} \mathrm{C}\right.$ ) for three durations of time (15 $\mathrm{min}, 30 \mathrm{~min}, 45 \mathrm{~min}$ ). The results showed that increase in exposure time decreased the MOE (modulus of elasticity) and MOR (modulus of rupture). The screw withdrawal strength of heat treated wood was lower than that of untreated wood.

Barboutis et al. (2011) studies the effects of short time thermal treatment (15 min and $30 \mathrm{~min}$ ) on dimensional stability and mechanical properties of lime wood (Tilia cordata). The results showed that the dimensional stability was increased for the heat treated wood, but the mechanical properties were decreased significantly. In our approach was considered the influence of short time heat treatment on variation of dimensional stability after the immersion of wood in water and the mass loss of Abies alba Mill. and Acer campestre L. Abies alba Mill. and Acer campestre L. are among the most wide spread species in Albanian forest and among the most used types of wood in Albanian wood industry. The sequences of heat treatment on wood properties were not studied till now for Albanian species and this survey can be considered a useful contribution in this field.

\section{MATERIALS AND METHODS}

The sample materials were collected in Saranda Region, south of Albania. The samples were sawn in dimensions $40 \times 40 \times 10 \mathrm{~mm}$ and there were put numbers for every sample. The samples were prepared according the UNI ISO 3130 standard. After this, the samples were conditioned to 8-9\% moisture content at $20^{\circ} \mathrm{C}$ and $60 \%$ relative humidity. This was 
done to prevent splitting and discoloration of wood during heat treatment. For each experiment and each type of wood 10 specimens were prepared. After this, for all the samples weight and the tangential and radial dimensions were measured.

Three different temperatures $\left(180^{\circ} \mathrm{C}, 200^{\circ} \mathrm{C}\right.$, $220^{\circ} \mathrm{C}$ ) and two different time durations of 15 and 30 minutes were applied to the samples. The samples were placed in the oven after the desired temperature was reached.

After the heat treatment, the weight is measured for the samples. After this, the samples were conditioned at $20^{\circ} \mathrm{C}$ and $60 \%$ relative humidity for ten days. The weight and dimensions were measured again after the conditioning and the weight loss is determined because of high temperature treatment.

All the samples were immersed in the water. The dimensions were measured after 1,4 and 6 days of immersion in water. For each species is calculated the swelling. Statistical analysis was performed using paired Student t-test, where $\mathrm{p}$ values $<0.05$ were considered as significant.

\section{RESULTS AND DISCUSSION}

\section{Maple and Fir Swelling as a Result of Thermal Treatment}

According to the results of the wood swelling measurements and analyzing the values in the
Tab. I and II, and correspondent charts it is noticed that swelling of wood (maple and fir) doesn't undergoes any considerable reduction by the thermal treatment at a temperature $180^{\circ} \mathrm{C}$, for 15 and 30 minutes respectively. This happen because the wall cell structure doesn't change under this temperature.

Wood swelling (maple and fir) undergoes a considerable reduction in the case of wood treatment at a temperature of $220^{\circ} \mathrm{C}$. Increasing the temperature to $220^{\circ} \mathrm{C}$ leads to a destroy of cell wall structure by reducing the ability of the wood to be associated with water molecules, thus to be swelled. Wood swelling (maple and fir) undergoes a considerable reduction in the case of wood treatment at a temperature of $220^{\circ} \mathrm{C}$ for the longest time duration of $30 \mathrm{~min}$. The statistical significance is reflected through the $\mathrm{p}<0.05$ (0.025 and 0.045 for the tangential treatment and 0.010 and 0.018 for the radial one in case of maple, while the values are in case of fir these values are respectively 0.037, 0.007 and 0.0012 for the tangential and radial thermal treatments).

According the Fig. 1 and Fig. 2 results that tangential swelling of maple wood presented through box plots thermally treated $\left(220^{\circ} \mathrm{C}\right.$ for $\left.30 \mathrm{~min}\right)$ decreases respectively $47 \%, 45.7 \%$ and $46.2 \%$ after 1,4 and 6 days immersion in water versus untreated wood. Radial swelling of maple wood, thermally treated $\left(220^{\circ} \mathrm{C}\right.$ for $\left.30 \mathrm{~min}\right)$ decreases respectively $48.2 \%$, $48.5 \%$ and $50.5 \%$ after 1,4 and 6 days immersion in water versus untreated wood.

I: Swelling percentage of thermally treated and untreated maple wood, ** denotes level of significance of 0.05

\begin{tabular}{|c|c|c|c|c|c|c|c|c|c|c|c|c|}
\hline MAPLE & \multicolumn{3}{|c|}{$180^{\circ}$} & \multicolumn{3}{|c|}{$200^{\circ}$} & \multicolumn{3}{|c|}{$220^{\circ}$} & \multicolumn{3}{|c|}{ Untreated } \\
\hline \multicolumn{13}{|c|}{ Tangential } \\
\hline $15 \mathrm{~min}$ & 9.43 & 9.60 & 9.90 & 9.12 & 9.57 & 9.85 & 8.91 & 9.23 & 9.61 & \multirow{4}{*}{9.66} & \multirow{4}{*}{9.70} & \multirow{4}{*}{9.95} \\
\hline $\mathrm{SD}$ & 0 & 0.17 & 0.47 & -0.39 & 0.06 & 0.34 & -0.34 & -0.02 & 0.36 & & & \\
\hline & \multicolumn{3}{|c|}{$0.071^{* *}$} & \multicolumn{3}{|c|}{$0.106^{* *}$} & \multicolumn{3}{|c|}{$0.025^{* *}$} & & & \\
\hline $30 \mathrm{~min}$ & 9.39 & 9.56 & 9.87 & 7.89 & 7.93 & 8.12 & 5.12 & 5.27 & 5.35 & & & \\
\hline $\mathrm{SD}$ & -0.29 & -0.04 & 0.27 & -0.01 & -0.05 & 0.14 & -0.12 & 0.03 & 0.11 & -0.11 & -0.07 & 0.18 \\
\hline \multicolumn{13}{|c|}{ Radial } \\
\hline $15 \mathrm{~min}$ & 3.74 & 3.89 & 4.01 & 3.56 & 3.72 & 3.95 & 3.47 & 3.59 & 3.72 & \multirow{5}{*}{4.15} & \multirow{5}{*}{4.52} & \multirow{5}{*}{4.87} \\
\hline SD & -0.14 & 0.01 & 0.13 & -0.18 & -0.02 & 0.21 & -0.12 & 0 & 0.13 & & & \\
\hline VAR & 0.009 & 0.005 & 0.008 & 0.016 & 0 & 0.021 & 0.007 & 0.0071 & 0.008 & & & \\
\hline & \multicolumn{3}{|c|}{$0.019 * *$} & \multicolumn{3}{|c|}{$0.007^{* *}$} & \multicolumn{3}{|c|}{$0.010^{* *}$} & & & \\
\hline $30 \mathrm{~min}$ & 3.70 & 2.76 & 3.91 & 2.21 & 2.54 & 2.67 & 2.15 & 2.33 & 2.41 & & & \\
\hline SD & 0.25 & -0.69 & 0.46 & -0.26 & 0.07 & 0.20 & -0.14 & 0.04 & 0.12 & 0 & 0.01 & 0.36 \\
\hline
\end{tabular}


II: Swelling percentage of thermally treated and untreated fir wood, ** denotes level of significance of 0.05

\begin{tabular}{|c|c|c|c|c|c|c|c|c|c|c|c|c|}
\hline \multirow{2}{*}{ FIR } & \multicolumn{3}{|c|}{$180^{\circ}$} & \multicolumn{3}{|c|}{$200^{\circ}$} & \multicolumn{3}{|c|}{$220^{\circ}$} & \multicolumn{3}{|c|}{ Untreated } \\
\hline & 1 day & 4days & 6days & 1 day & 4days & 6days & 1 day & 4days & 6days & 1 day & 4days & 6days \\
\hline \multicolumn{13}{|c|}{ Tangential } \\
\hline $15 \mathrm{~min}$ & 6.82 & 6.96 & 7.24 & 6.73 & 6.85 & 7.12 & 6.5 & 6.65 & 6.95 & \multirow{5}{*}{6.91} & \multirow{5}{*}{7.02} & \multirow{5}{*}{7.21} \\
\hline SD & -0.18 & -0.04 & 0.24 & -0.17 & -0.05 & 0.22 & -0.2 & -0.05 & 0.25 & & & \\
\hline \multirow[t]{2}{*}{ VAR } & 0.017 & 0.001 & 0.027 & 0.014 & 0.001 & 0.024 & 0.02 & 0.001 & 0.031 & & & \\
\hline & \multicolumn{3}{|c|}{$0.203^{* *}$} & \multicolumn{3}{|c|}{$0.176^{* *}$} & \multicolumn{3}{|c|}{$0.037^{* *}$} & & & \\
\hline $30 \mathrm{~min}$ & 6.78 & 6.92 & 7.14 & 5.02 & 5.11 & 5.92 & 2.32 & 2.71 & 2.84 & & & \\
\hline SD & -0.16 & -0.02 & 0.20 & -0.33 & -0.24 & 0.57 & -0.3 & 0.09 & 0.22 & -0.12 & -0.02 & 0.17 \\
\hline \multirow[t]{2}{*}{ VAR } & 0.013 & 0 & 0.018 & 0.054 & 0.028 & 0.162 & 0.046 & 0.003 & 0.023 & 0.009 & 0 & 0.013 \\
\hline & \multicolumn{3}{|c|}{$0.184^{* *}$} & \multicolumn{3}{|c|}{$0.048^{* *}$} & \multicolumn{3}{|c|}{$0.007^{* *}$} & \multicolumn{3}{|c|}{1.303} \\
\hline \multicolumn{13}{|c|}{ Radial } \\
\hline $15 \mathrm{~min}$ & 2.18 & 2.28 & 2.56 & 2.05 & 2.10 & 2.49 & 1.81 & 1.99 & 2.26 & & & \\
\hline SD & -0.16 & -0.06 & 0.22 & -0.16 & -0.11 & 0.28 & -0.45 & -0.03 & 0.24 & & & \\
\hline \multirow[t]{2}{*}{ VAR } & 0.012 & 0.001 & 0.024 & 0.013 & 0.006 & 0.038 & 0.022 & 0 & 0.028 & 2.75 & 3.01 & 3.38 \\
\hline & \multicolumn{3}{|c|}{$0.052^{* *}$} & \multicolumn{3}{|c|}{$0.031^{* *}$} & \multicolumn{3}{|c|}{$0.0012^{* *}$} & & & \\
\hline $30 \mathrm{~min}$ & 2.07 & 2.17 & 2.32 & 1.07 & 1.48 & 2.03 & 0.94 & 1.12 & 1.24 & & & \\
\hline SD & -0.11 & -0.01 & 0.14 & -0.45 & -0.04 & 0.11 & -0.07 & 0.01 & 0.13 & -0.29 & -0.03 & 0.34 \\
\hline \multirow[t]{2}{*}{ VAR } & 0.006 & 0 & 0.008 & 0.104 & 0.001 & 0.126 & 0.0128 & 0 & 0.009 & 0.044 & 0 & 0.055 \\
\hline & \multicolumn{3}{|c|}{$0.008^{* *}$} & \multicolumn{3}{|c|}{$0.0019^{* *}$} & \multicolumn{3}{|c|}{$0.0012^{* *}$} & \multicolumn{3}{|c|}{$0.100^{*}$} \\
\hline
\end{tabular}
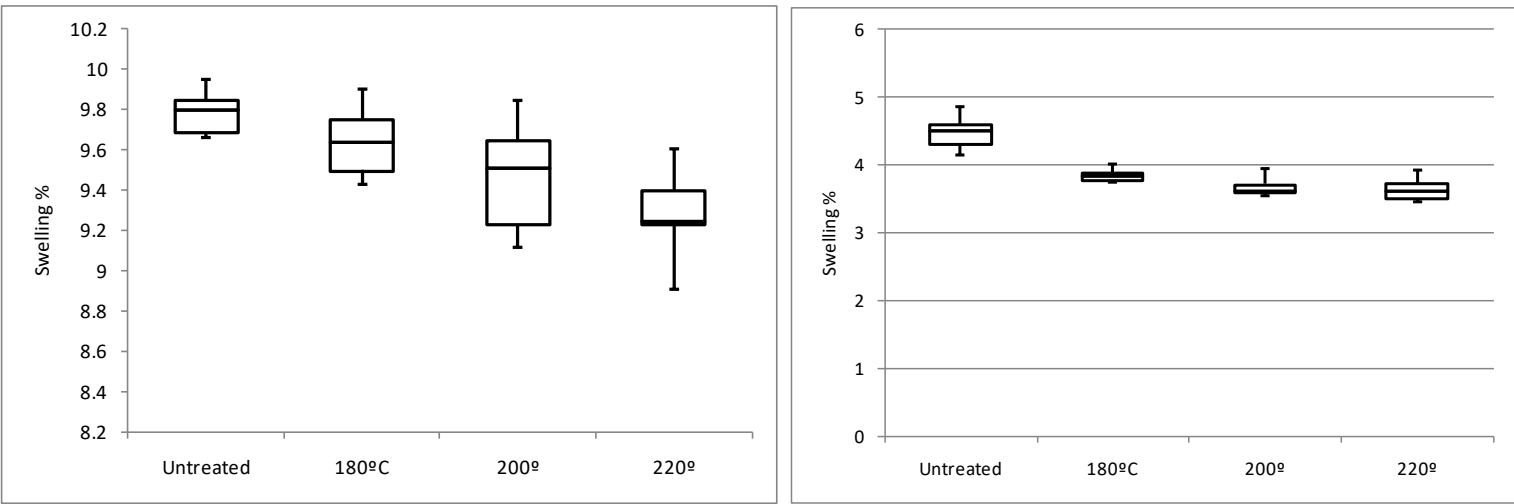

1: Box-plot of swelling percentage distribution of maple for $15 \mathrm{~min}$ (Left tangential and right radial treatment)
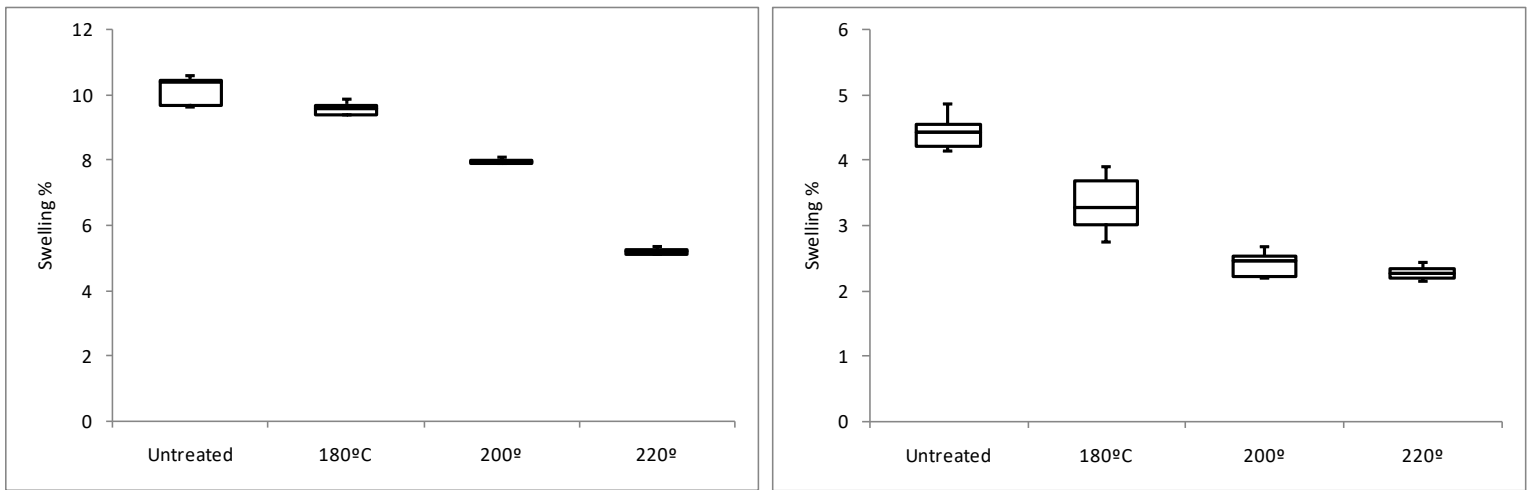

2: Box-plot of swelling percentage distribution of maple for 30 min (Left tangential and right radial treatment) 

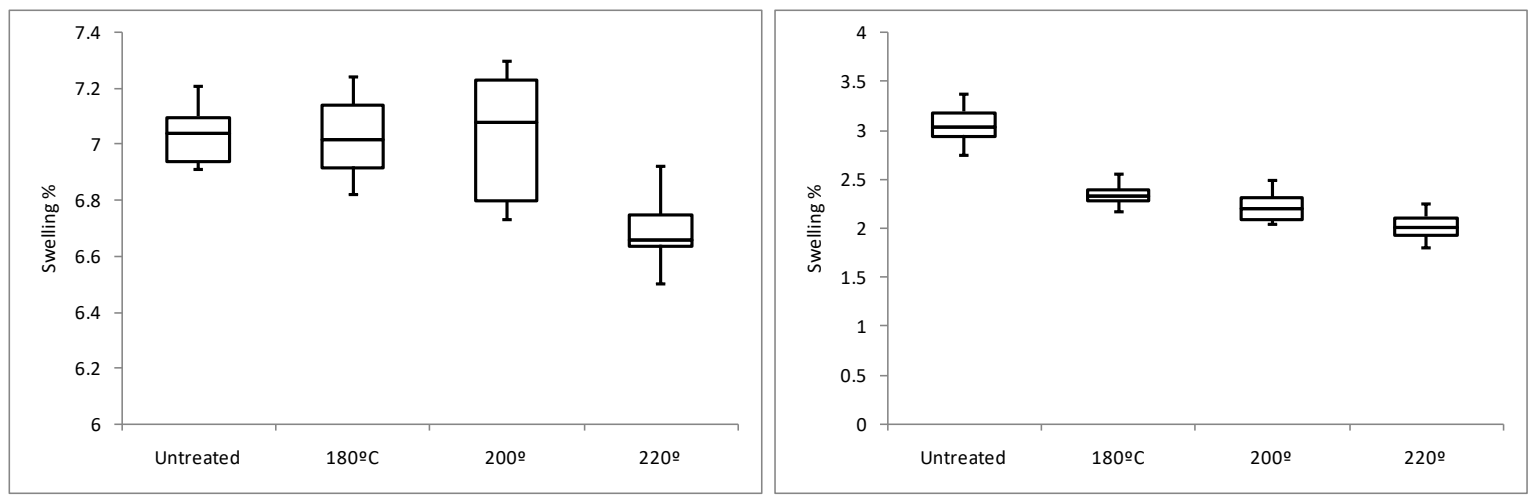

3: Box-plot of swelling percentage distribution of fir for $15 \mathrm{~min}$ (Left tangential and right radial treatment)
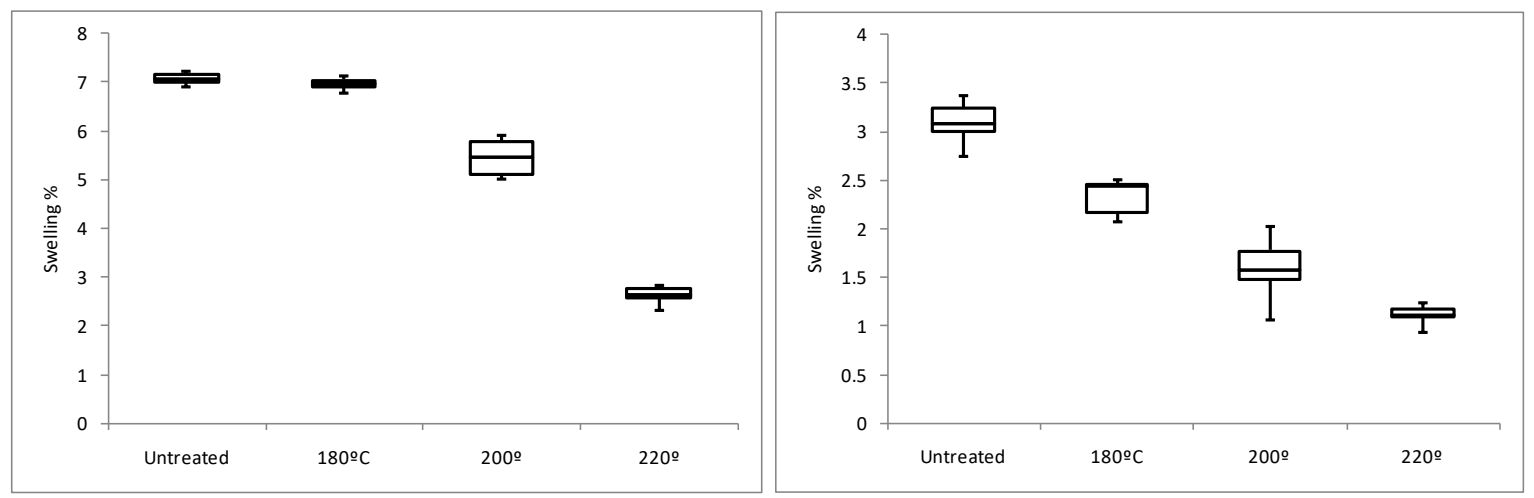

4: Box-plot of swelling percentage distribution of fir for $30 \mathrm{~min}$ (Left tangential and right radial treatment)

As is it is presented in Fig. 3 and 4 the tangential swelling of fir wood thermally treated $\left(220^{\circ} \mathrm{C}\right.$ for $30 \mathrm{~min}$ ) decreases respectively $66.4 \%, 61.4 \%$ and $60.6 \%$ after 1, 4 and 6 days immersion in water versus untreated wood. Radial swelling of fir wood, thermally treated $\left(220^{\circ} \mathrm{C}\right.$ for $\left.30 \mathrm{~min}\right)$ decreases respectively $65.8 \%, 62.8 \%$ and $63.3 \%$ after 1 , 4 and 6 days immersion in water versus untreated wood. The box plot showed in the Fig. 4 for the radial treatment of the fir in both $200^{\circ} \mathrm{C}$ and $220^{\circ} \mathrm{C}$ very narrow variability around middle value (1.07, 1.48, 2.03 and $0.94,1.12,1.24$ respectively).

\section{Maple and Fir Weight Changes as a Result of Thermal Treatment}

a) The wood weight loss is calculated directly after the thermal treatment and according Tab. III and Tab. IV, and it is seen that the lower percentage of weight loss after the thermal treatment $(8.76 \%$ for the maple and $7.12 \%$ for the fir) was measured in the samples treated in a $180^{\circ} \mathrm{C}$ for $15 \mathrm{~min}$. The values are statistically significant $\mathrm{p}<0.05$ (0.024). This happen because under these conditions of thermal treatment, the main effect that has affected weight loss was only the evaporation of water without destroying the wall structure. Similar results were gained by Barboutis et al. (2011), Boonstra et al. (1998), etc. The higher percentage of

III: Percent of weight loss after thermal treatment, weight increase and $p^{*}$ value at $\alpha=0.05$ after air conditioning for maple

\begin{tabular}{|c|c|c|c|c|c|c|}
\hline & $15 \mathrm{~min}$ & $30 \mathrm{~min}$ & $15 \mathrm{~min}$ & $30 \mathrm{~min}$ & $15 \mathrm{~min}$ & $30 \mathrm{~min}$ \\
\hline Temperature & $180^{\circ} \mathrm{C}$ & $180^{\circ} \mathrm{C}$ & $200^{\circ} \mathrm{C}$ & $200^{\circ} \mathrm{C}$ & $220^{\circ} \mathrm{C}$ & $220^{\circ} \mathrm{C}$ \\
\hline Weight loss (\%) & 8.76 & 9.6 & 8.85 & 9.62 & 9.2 & 9.66 \\
\hline Standard Dev. & 2.4 & 1.2 & 3.77 & 0.34 & 2.07 & 0.27 \\
\hline$p$ value $\alpha=0.05$ & \multicolumn{2}{|c|}{0.024} & \multicolumn{2}{|c|}{0.026} & \multicolumn{2}{|c|}{0.082} \\
\hline Weight increase (\%) & 4.14 & 4.61 & 4.37 & 4.87 & 4.58 & 3.92 \\
\hline Standard Dev. & 1.1 & 1.02 & 1.07 & 1 & 0.7 & 0.5 \\
\hline$p$ value $\alpha=0.05$ & \multicolumn{2}{|c|}{0.031} & \multicolumn{2}{|c|}{0.052} & \multicolumn{2}{|c|}{0.01} \\
\hline
\end{tabular}


IV: Percent of weight loss after thermal treatment, weight increase and $p^{*}$ value at $\alpha=0.05$ after air conditioning for fir

\begin{tabular}{|c|c|c|c|c|c|c|}
\hline Time duration & $15 \mathrm{~min}$ & $30 \mathrm{~min}$ & $15 \mathrm{~min}$ & $30 \mathrm{~min}$ & $15 \mathrm{~min}$ & $30 \mathrm{~min}$ \\
\hline Temperature & $180^{\circ} \mathrm{C}$ & $180^{\circ} \mathrm{C}$ & $200^{\circ} \mathrm{C}$ & $200^{\circ} \mathrm{C}$ & $220^{\circ} \mathrm{C}$ & $220^{\circ} \mathrm{C}$ \\
\hline Weight loss (\%) & 7.12 & 8.85 & 9.13 & 10.66 & 10.44 & 10.77 \\
\hline Standard Dev. & 1.3 & 0.65 & 1.27 & 1.59 & 0.45 & 0.52 \\
\hline$p$ value $\alpha=0.05$ & \multicolumn{2}{|c|}{0.500} & \multicolumn{2}{|c|}{0.037} & \multicolumn{2}{|c|}{0.491} \\
\hline Weight increase (\%) & 3.83 & 4.35 & 4.52 & 4.87 & 4.95 & 3.87 \\
\hline Standard Dev. & 0.1 & 0.1 & 0.84 & 1 & 0.1 & 0.16 \\
\hline$p$ value $\alpha=0.05$ & \multicolumn{2}{|c|}{0.0108} & \multicolumn{2}{|c|}{0.450} & \multicolumn{2}{|c|}{0.100} \\
\hline
\end{tabular}

weight loss after the thermal treatment $(9.66 \%$ for the maple and $10.77 \%$ for the fir) was measured in the samples treated in a $220^{\circ} \mathrm{C}$ for 30 minutes reflected through no statistical significance with $p>0.05$ (0.082). This is because due to the harsh conditions of thermal treatment, the chemical components of the cell wall structure have undergone significant transformations which have led to the loss of weight of the wood. The treatment in higher temperature caused higher depolymerization of hemicelluloses, consequently there was less water absorption in the cell wall (Boonstra et al., 1998; Esteves et al., 2008).

b) The wood weight increase after the thermally treated wood is conditioned in $\mathrm{T}=20^{\circ} \mathrm{C}$ and $\varphi=60 \%$ for 10 days. Tab. III and IV, show that the lower percentage of weight gain after the thermal treatment and the air conditioning (4.14\% for the maple and $3.83 \%$ for the fir) was measured in the samples treated in mild treatment in $180^{\circ} \mathrm{C}$ for $15 \mathrm{~min}$. This result is because the samples have not managed to lose all initial moisture during thermal treatment.

The higher percentage of weight gain after the thermal treatment and the air conditioning (3.92\% for the maple and $3.87 \%$ for the fir) was measured in the samples treated in $220^{\circ} \mathrm{C}$ for 15 minutes in case of fir samples ( $p>0.05$ ). This result is obtained because the samples after this thermal treatment reduced initial humidity, left all the volatile extractives but not yet reached the significant modifications of the structure of the cell wall. This has been confirmed also by Rüggeberg and Burgert, 2015; Grönquist et al., 2019, etc.

\section{CONCLUSION}

In this study two types of wood samples were subjected of short heat treatment at three different temperatures $\left(180^{\circ} \mathrm{C}, 200^{\circ} \mathrm{C}, 220^{\circ} \mathrm{C}\right)$ at two different duration times $(15 \mathrm{~min}$ and $30 \mathrm{~min})$. The effect of short heat treatment on tangential and radial swelling and dimensional stability was investigated. The differences in thermal treatment were confirmed through statistical analyses as well.

The basic effect of high temperature treatment was on reducing wood swelling. The reducing of radial and tangential swelling was greater when samples were treated in highest temperature for 30 min which differed statistically significant from the corresponding values of the other treated samples in both wood species. The thermal treatment of wood for time duration $15 \mathrm{~min}$ does not have any significant effect on wood properties because the treatment does not change the wall structure. The reduction of wood swelling is greater for fir than maple. This can be explained with the fact that the maple wood is rich in extractives (the fir doesn't have extractives) so a part of thermal treatment time of maple wood goes for the disconnection of the extractives from the wall cell structure, while in the case of fir wood the thermal treatment time effects directly in the structure of wall cell.

\section{REFERENCES}

AKYILDIZ, M. H., ATES, S. and ÖZDEMIR, H. 2009. Technological and chemical properties of heattreated Anatolian Black pine wood. African Journal of Biotechnology, 8(11): 2565-2572.

BARBOUTIS, I., VASILEIOU, V., MITANI, A. and KAMPERIDOU, V. 2011. Effects of short time thermal treatment on some properties of wood lime. Pro Ligno, 7(4): 39-49.

BARTŁOMIEJ, M., ROMAN, Z., WOJCIECH, G., GRZEGORZ, C. and MARIA, B. 2004. Resistence of thermally modified wood of basidiomycetes. Electronic Journal of Polish Agricultural Universities (EJPAU), 7: 221-234. 
BOONSTRA, M., TJEERDSMA, B. and GROENEVELD, H. 1998. Thermal Modification of Non-Durable Wood Specifies. Part 1. The Plato technology: thermal modification of wood. Document No. IRG/WP 98-40123. International Research Group Wood Preservation.

BOURGOIS, J. and GUYONNET, R. 1988. Characterization and analysis of torrefied wood. Wood Sci. Technl., 22: 143-155.

BURMESTER, A. 1973. Investigation on the dimensional stabilization of wood. Berlin: Dahlem.

ESTEVES, B., DOMINGOS, I. and PEREIRA, H. 2008. Pine wood modification by heat treatment in air. Bioresources, 3(1): 142-154.

CHANRION, P. and SCHREIBER, J. 2002. Les Différents Procédés, Bois Traité par Haute Température. Paris: Edition CTBA.

GRÖNQUIST, P., WOOD, D., HASSANI, M., WITTEL, F., MENGES, A. and RÜGGEBERG, M. 2019. Analysis of hygroscopic self-shaping wood at large scale for curved mass timber structures. Sci. Adv., 5(9): eaax1311.

GUNDUZ, G., KORKUT, S., AYDEMIR, D. and BEKAR, İ. 2009. The Density, Compression Strength and Surface Hardness of Heat Treated Hornbeam (Carpinus betulus L.) Wood. Maderas. Ciencia y tecnología, 11(1): 61-70.

HAKKOU, M., PETRISSANS, M., GERARDIN, P. and ZOULALIAN, A. 2006 Investigations of the reasons for fung durability of heat-treated beech wood. Polymer Degradation and Stability, 91(2): 393-397.

HILLIS, W. 1984. High temperature and chemical effects on the wood stability. Part 1, General considerations. Wood Sci. Technol., 18: 281-293.

HILL, C. 2006. Wood Modification-Chemical, Thermal and Other Processes. Wiley Series in Renewable Resources. John Wiley \& Sons, Ltd.

HOLSTOV, A., BRIDGENS, B. and FARMER, G. 2015. Hygromorphic materials for sustainable responsive architecture. Construct. Build Mater., 98: 570-582.

KOCAEFE, D., PONCSAK, S. and BOLUK, Y. 2008. Effect of thermal treatment on the chemical composition and mechanical properties of birch and aspen. Bioresources, 3(2): 517-537.

KOCAEFE, D., PONCSAK, S., TANG, J. and BOUAZARA, M. 2010. Effect of heat treatment on the mechanical properties of North American jack pine: thermo gravimetric study. Journal of Material Science, 45(3): 681-687.

KOLLMAN, F. 1936. Technologie des Holzes und der Holzwerkstoffe. Berlin: Springer Verlag.

KOLLMANN, F. and SCHNEIDER, A. 1963. On the sorption behavior of heat stabilized wood. Holz RohWerkst, 21(3): 77-85.

KOLLMANN, F. and FENGEL, D. 1965. Changes in the chemical composition of wood by heat treatment. Holz Roh-Werks, 12: 461-468.

MBURU, F., DUMARCEAY, S., HUBER, F., PETRISSANS, M. and GERARDIN, P. 2007. Evaluation of thermally modified Grevillea robusta heartwood as an alternative to shortage of wood resource in Kenia: Characterisation of physicochemical properties and improvement of bio-resistance. Bioresource Technology, 98(18): 3478-3486.

MILITZ, H. 2002. Thermal treatment of wood: European processes and their background. Document No. IRG/WP 02-40241. Stockholm, Sweden: International Research Group on Wood Protection.

RÜGGEBERG, M. and BURGERT, I. 2015. Bio-inspired wooden actuators for large scale applications. Plus One, 10(4): e0120718.

SAILER, M., RAPP, A. and LEITHOFF, H. 2000. Improved resistance of Scots pine and spruce by application of an oil-heat treatment. Section 4-Processes. Doc. No. IRG/WP 00-40162 International Research Group Wood Preservation.

STAMM, A. and HANSEN, L. 1937. Minimizing wood and swelling: Effect of heating in various gases. Ind. Eng. Chem., 29(7): 831-833.

SEBORG, R., MILLET, M. and STAMM, A. 1945. Heat-stabilizied compressed wood. Staypack. Mech. Eng., 67(1): 25-31.

SEBORG, R., TARKOW, H. and STAMM, A. 1953. Effect of heat upon the dimensional stabilization of wood. J. For. Prod. Res. Soc., 3(9): 59-67.

SHI, J. L., KOCAEFE, D. and ZHANG, J. 2007. Mechanical behavior of Quebec wood species heat-treated using ThermoWood process. Holz Roh Werkst., 65: 255-259.

VERNOIS, M. 2001. Heat treatment of wood in France - State of art. In: RAPP, A. O. (Ed.). Proceedings of Special seminar "Review on Heat Treatment of Wood". Antibes, France February 9, 2001. Hamburg: $\mathrm{BFH}$ the federal research Centre for forestry and forest products, pp. 39-46.

YILDIZ, S., GEZER, D. and YILDIZ, U. 2006. Mechanical and chemical behavior of spruce wood modified by heat. Building Environ., 41(21): 1762-1766.

WEILAND, J. J. and GUYONNET, R. 2003. Study of chemical modifications and fungi degradation of thermally modified wood using DRIFT spectroscopy. Holz Roh-Werkst., 61(2): 216-220. 
Contact information

Laura Shumka: shumkalaura@gmail.com (c) $\left(\begin{array}{l}\text { (i) } \\ \text { (CY }\end{array}\right.$ This work is licensed under a Creative Commons Attribution-NonCommercial-NoDerivatives 4.0
(CC BY-NC-ND 4.0) International License 